This is a post-print of 'Fonteyn L. (2018), A corpus-based view on the (aspectual-)semantics of Modern English nominalizations, Language Sciences. It has been published online by Elsevier: https://doi.org/10.1016/j.langsci.2018.08.008

\title{
A corpus-based view on the (aspectual-)semantics of Modern English nominalizations
}

\section{Abstract}

In this response article, I will challenge some of the claims presented by Iordăchioaia \& Werner by suggesting that English ing-nominals were not prevented from completing the 'cycle of categorial shift', and questioning the actual impact of the competition with Romance derived nominals on the specialization of ing-nominals with event denotation (i.e. nominal gerunds). The response is based on a detailed corpus-based analysis of Penn corpora of Modern English (PPCEME \& PPCMBE, time span: 1500-1920), and consists of three components: (i) a summary of a recent study by Fonteyn \& Hartmann (2016), in which it is argued that nominal gerunds do complete the full nominalization cycle from eventive to concrete object meanings, (ii) a more fine-grained aspectual-semantic analysis of eventive ing-nominals (or nominal gerunds), and (iii) a detailed comparison between ing-nominals and Romance derived nominals in -age, -al, -ance, -ion, and -ment, mapping out the areas of overlap and the effect of competition on the semantic development of the different nominalization strategies. In the conclusion, it is argued that the intriguingly versatile usage profile of English ing-nominals in Modern English is shaped by a constant diachronic interaction with their neighbouring constructions.

\section{Introduction}

In their explorative theoretical study, Iordăchioaia \& Werner (this issue) advance the hypothesis that the semantic differences between English ing-nominals (to be understood here as a cover term for all nominal ing-forms in English, including non-eventive ing-nominals, e.g. the old building, as well as nominal gerunds denoting actions or events, e.g. the meticulous checking of references, but excluding verbal gerunds, e.g. meticulously checking references) and German ung-nominals attested in the present-day variants of the languages results from diverging diachronic developments. The main topic they address is the aspectualsemantic difference between the two forms, i.e. the different ways in which the internal temporal constituency and boundaries of the situations they express is viewed (Comrie, 1976; Lyons, 1977, pp. 710-711; Smith, 1997, p. 3; Sasse, 2002, p. 201). The aspectual difference Iordăchioaia \& Werner describe is one of 'process' versus 'result' semantics, which corresponds to thedichotomy between situations that are construed without boundaries and situations which include a 'natural' endpoint and result state, also called 'telos'; cf. Janda, 2008). More specifically, Iordachioaia \& Werner suggest that English ing-nominals retained their processual semantics because a series of nominalization strategies borrowed from French prevented them from acquiring result-oriented or telic semantics. They relate this observation to the loss of grammatical gender in English, which occasioned an increase in mass semantics in English.

An interesting claim that emerges from Iordăchioaia \& Werner's discussion is that the proposed aspectual-semantic distinction between Present-day English ing-nominals which are said to refer to processes - and the more 'result-oriented' German ung-nominals 
reflects a (semantic) difference in categoriality. In this respect some of Iordachioaia \& Werner's claims echo the programmatic claim made by functional and cognitive linguists that there is a notional or functional basis underlying grammatical categories such as 'noun' and 'verb' (e.g. Hopper \& Thompson, 1985; Langacker, 1987; Croft, 1991; Taylor, 1995). Accounts that argue in favor of such a 'notional' definition of nouns and verbs generally argue two things: first, that grammatical categories, like everyday categories, are centered around a conceptual prototype and comprise typical and untypical members, and second, that it is possible to put forward an abstract schematic definition or template that generalizes over and captures all members of the category (e.g. Langacker, 1987). Accordingly, despite the undeniable diversity of the concepts denoted by the grammatical categories 'noun' and 'verb', nouns are essentially characterized as stable containers of information, while verbs are transitory or sequential relational concepts (e.g. Sapir, 1921, pp. 117-119; Bolinger, 1980, p. 27; Gentner, 1981, p. 176; Hopper \& Thompson, 1984; Langacker, 1987, 2008a, 2008b; Croft, 1991, 2000, 2001; Schmid, 1999, p. 221-222; Mihatsch, 2009; also see Fonteyn, 2016 and the discussion in Hartmann, this issue). ${ }^{1}$ These abstract characterizations of 'noun' and 'verb' are considered to be maximally opposite (Langacker, 1987), as they are centered around the two maximally differing conceptual prototypes of concrete objects with distinctive shape/boundaries/delineation (or 'THING' for nouns) and physical actions (or 'PROCESS' for verbs) (e.g. Lyons, 1968, p. 318; Bates \& MacWhinney, 1982; Hopper \& Thompson, 1985;). ${ }^{2,3}$ Generalizing over all specific occurrences of English V-ing and German V-ung, Iordăchioaia \& Werner argue that the concepts denoted by formations with English -ing like beating, walking, and destroying closely adhere to the verbal conceptual prototype of ongoing dynamic action, while formations with German -ung such as Wertung ('rating'), and Zerstörung ('destruction') typically_involve reference to a result state or telos and are thus more delineated and less processual (implying that such delineation is a nominal trait; for a similar discussion see, among others, Hartmann (2014) and Demske (this issue)). Similarly, it has been argued that process readings of German ung-nominals are on the whole rather marked, whereas concrete object readings are common (Erich \& Rapp, 2000), which is supposedly not the case for English ing-nominals (Demske, 2002; Bauer, Lieber \& Plag, 2013; Borer, 2013).

Turning to the question how this categoriality difference between the two historically related suffixes -ing and -ung came about, Iordăchioaia \& Werner suggest that German ungnominals fully completed the so-called 'cycle of categorial shift' from a processual verbnoun hybrid to a more prototypical nominal, while English ing-nominals were prevented from doing so. Diachronically, there appears to be an interesting and cross-linguistically well-

\footnotetext{
${ }^{1}$ In Cognitive Grammar, these abstract templates have been linked to how nouns and verbs are processed and conceptualized by language users: nouns are conceptually independent entities which are summarily scanned (i.e. conceived of as stable discourse units), while verbs are scanned sequentially (Langacker 2008b).

${ }^{2}$ Crucially, these conceptual prototypes are not considered as conditions for or determinants of morphosyntactic categoriality; that is, it is certainly not claimed that ball and man are in any way 'better' nouns than war and birth. I have argued elsewhere that prototypical nominality on the functional-semantic level is most likely a cluster concept comprising of intersecting semantic and discourse-functional properties (see Fonteyn 2016, where I build on the ideas presented in Croft (2001) and Langacker (2008a)), and it still remains to be empirically verified if morphosyntactic and functional-semantic prototypicality can be aligned. For reasons of brevity, and because the present study merely deals with semantic change (and hence no claims are made about morphosyntactic categoriality), I will not go into detail here.

${ }^{3}$ For an overview of psycholinguistic research supporting the view that nouns are associated with the conceptual prototype THING; see the discussion in Mihatsch (2009).
} 
attested tendency for untypical nouns to be attracted towards typical core nouns. While processes of semantic change are sometimes idiosyncratic (see Hartmann, 2014, p. 8), Mihatsch (2009, p. 83) explains that such untypical nouns quite frequently develop along a pathway "of unconscious reification triggered by the conceptual noun schema", which is "not caused exclusively by any external factors such as cultural influences (although extralinguistic information provides the semantic material)". One such recurring pathway involves deverbal nominalizations, which tend to undergo "categorial change of meaning (...) for which the term 'drift' (...) seems convenient" (Panagl, 1987, p. 146). It is suggested that this semantic attraction to the nominal prototype occurs gradually, and "tends to proceed through the level of resultative noun (nomen acti) and in many cases reaches the level of concrete noun (interpretable as instrumental or local)" (Panagl, 1987, p. 146). It is this 'drift' in denotational properties of nominalization patterns - going from processual meaning to a more delineated resulting product - that is said to have affected German ung-nominals, but not English ing-nominals. Bauer, Lieber \& Plag (2013, p. 208), for instance, conclude that nominalizations in -ing "characteristically display eventive [i.e. verb-like] readings and are less prone to (...) semantic drift" than other nominalization strategies in English such as zeroaffixation, and related patterns in other languages, like German ung-nominalization (see also Demske, 2002).

In this response article, I would like to question the proposed characterization of English ing-nominals by pointing out that (i) English ing-nominals may not have been prevented from completing the cycle of categorial shift, and (ii) the overall diachronic impact of the specialization of ing-nominals with event denotation (also called nominal gerunds), which Iordachioaia \& Werner suggest was evoked by their competition with Romance derived nominals (in -age, -al, -ance, -(at)ion, -ment), might have been limited. First, I present some methodological issues that are crucial to the semantic study of aspect in presentday as well as historical stages of a language (Section 2). I will then map out the different uses of English ing-nominals as they were attested in the Penn Corpora of Modern English (covering the time span between 1500-1920) in Section 3. This section consists of three components. Section 3.1 provides a summary of a recent study by Fonteyn \& Hartmann (2016), in which it is argued that ing-nominals increasingly refer to concrete objects. Subsequently, I will take a more fine-grained perspective on eventive ing-nominals (or nominal gerunds). In Section 3.2, I will set out the different aspectual types nominal gerunds express, and show that they are neither limited to nor specialized in presenting atelic processes. This also becomes evident in Section 3.3, where the usage profile of English ingnominals is compared to that of Romance derived nominals in -age, -al, -ance, -(at)ion (henceforth -ion), and -ment. Section 4, finally, concludes this response article by arguing that, in usage, English ing-nominals are intriguingly semantically versatile due to a constant diachronic interaction with their neighboring constructions.

\section{Aspect and nominalization in Present-day English: A methodological note}

Regarding the aspectual features of nominal gerunds in Present-day English, Iordăchioaia \& Werner (this issue) suggest that "-ing exhibits a preference for atelic verbs and the nominal it derives highlights process readings". In other words, there is a selected set of verbs available in the lexicon (preferably atelic ones such as run, work, read, etc.) that may occur as a base verb in the ing-nominal construction, which therefore ultimately refers to a process (that is atelic or ongoing). While Iordăchioaia \& Werner seem to regard the aspectual selection of 
base verbs as related to (even causing) the processual semantics of the ing-nominal, I believe that they conflate two distinct levels of analysis: one regarding the combinatory potential of nominal gerunds (which base verbs can be used in the nominal gerund construction), and another one regarding the aspectual semantics of nominal gerunds. This becomes evident when Iordăchioaia \& Werner (this issue) state that "-ing is not excluded with result/telic verbs (...), but -ing does emphasize the process part of an event", suggesting that the nominal gerund projects a specific 'processual' construal on the verbs that occur in it. In this respect, their claims are reminiscent of Brinton (1998, p. 48), who proposes that English ingnominalizations do not preserve the aspectual features of their base verb, but "convert a situation into an activity, (...) making the situation durative, atelic, and dynamic". Thus, even though arriving is in principle a telic verb, a sentence like *His arriving occurred at 5:00 is considered ungrammatical because the ing-nominal yields an atelic process.

The issue I would like to raise before moving on to the analysis of nominalization in Modern English is that it is perhaps more difficult to verify and uphold such claims than it might initially seem. The assumption that lies at the heart of the hypothesis presented by Iordăchioaia \& Werner is that it is possible to tease the basic or 'default' aspectual type of a verb out of its linguistic context, and subsequently contrast it with the aspectual output of the contexts in which it occurs. Yet, in a wide range of aspectual studies, it is argued that the semantic distinction of telicity/atelicity can be ascribed to a wide variety of (complex) expressions, ranging from lexical verbs to verb phrases and even full sentences (see, e.g., Verkuyl, 1972; Nordenfelt, 1977, pp. 34-36; Dowty, 1979, pp. 61-65; Mittwoch, 1980, pp. 206-211; Mourelatos, 1981, pp. 196-197; Mommer 1986, pp. 61-62; Moens, 1987, pp. 150151; Brinton, 1988, pp. 26, 45-50; Shi, 1990, pp. 48-50; Binnick, 1991, p. 191; Smith, 1991; Depraetere, 1995, p. 4; Croft, 2012, pp. 31, 69). For instance, whether or not wrote has an endpoint depends on whether it combines with a single count noun object (making it telic) or a bare plural or abstract/mass object noun (resulting in an atelic activity):

(1) I wrote a postcard. [telic]

(2) I wrote postcards/poetry. [atelic]

Similarly, contextual factors like adverbs can determine whether the action expressed by the verb should be interpreted as instantaneous or 'punctual', or whether it is 'durative' and lasts for a certain stretch of time:

(3) Denise touched the water with her finger (quickly / for a few minutes).

As such, the aspectual meaning "is carried by the interaction of various linguistic features" (Freed, 1979, pp. 12-14) and is not confined to verb lexemes. Due to the wide range of factors that affect the aspectual semantics of verb lexemes and the constructions they occur in, we find that, in practice, many verb predicates in English acquire different meanings as they are used in different contexts, allowing "at least two or three [aspectual] construals" (Croft, 2012, p. 84). To tease apart aspectual import and contextual factors, it is assumed that each verb lexeme has a basic 'lexicalized' aspectual type (Rappaport Hovav \& Levin, 2010), which can then be transformed into or recategorized as another type by adding additional elements. For instance, the lexeme read can be analysed as an activity, which is turned into an accomplishment when the direct object a book is added (see Poutsma, 1926, p. 291; Vlach, 1981, p. 274; Moens \& Steedman, 1988; Herweg, 1991, p. 363). Similarly, a lexeme like destroy is assumed to be inherently telic, but it is recategorized as an (atelic, ongoing) activity (or in some models, as a state; see Parsons, 1990; Michaelis, 2004) when used in the 
progressive he is destroying our lives. To verify the hypothesis that nominal gerunds preferably combine with atelic verbs and construe situations as processual, then, the researcher has to assume an 'inherent' or basic aspectual type for all verb lexemes.

One problem here is to decide how we can (or should) determine the basic or 'default' aspectual type of a verb lexeme. In more theoretical approaches to aspectual semantics, it is simply assumed that the analyst can easily distinguish the default aspectual type of a verb lexeme from the aspectual construal that is imposed on it through contextual features, by decontextualizing it, or using it in a 'neutral aspectual context'. Yet, it has been argued that this might not be as straightforward as it appears, as "every occurrence of a verb is in a definite context, and there is no obvious way of determining what a "neutral aspectual context' would be like" (Dahl, 1985, pp. 26-27). Moreover, it is possible to think of cases where one simply cannot depend on intuition to determine a verb lexeme's default aspectual type: while it seems highly likely that the default interpretation of a verb like die is telic (as it implies a telos, i.e. death), it is much harder to intuitively characterize a verb like touch as inherently punctual or durative.

Keeping in mind the issues raised here, I believe there are a few ways to empirically verify the hypothesis presented by Iordăchioaia \& Werner. The first would be to determine which verb lexemes (or predicates) occur as ing-nominals through a more data-driven approach, using either systematically elicited (questionnaire) data or corpus data (or a combination of both). With a considerably large data set, the analyst can make somewhat more 'objective' claims about the relative 'acceptability' of word formations by determining their token frequency and comparing it to the token frequency of their base verb elsewhere in the data (e.g. a collostructional analysis (Gries \& Stefanowitsch, 2004) will test whether particular base verbs are attracted or repelled by a construction). Similarly, the analyst can attest the number of aspectual construals (state, activity, etc.) for each verb lexeme (e.g. read, touch) or predicate (e.g. read the/this/that/a book), as well as the relative frequency of each construal. This allows the analyst to determine whether the base verb has a default aspectual sense, which can then be compared to the (preferred) occurrence of base verbs in nominal gerunds or other types of nominalization strategies. As such, there should be less reliance on arbitrary judgments of default aspectual semantics (see also Brinton, 1988, p. 31). Another way to approach the study of aspectual semantics of deverbal nominalization patterns is by assuming only one level of analysis, focusing on the aspectual semantics of for instance nominal gerunds solely in context (or, in other words, without decontextualizing the base verb). For present-day English gerunds, this approach has been applied by Heyvaert, Maekelberghe \& Buyle (this issue. Using a sample of 500 nominal gerunds (and 500 verbal gerunds), they quantitatively mapped out the aspectual-semantic profile of English gerunds, considering the various contexts in which they are used. From their analysis, it emerged that the a substantial number of nominal gerunds construed the situation as telic, leading them to conclude that the nominal gerund construction might well be aspectually neutral rather than 'processual' (also see De Smet \& Heyvaert, 2011).

The remarks presented here have mainly focused on issues arising in the literature on aspectual semantics in present-day language, but they are critical for the analysis of historical data as well. In particular, while it might be a point of contention whether the analyst can rely on introspective native speaker judgments to determine the default aspectual semantics of decontextualized base verbs in present-day language, it seems unlikely that they would be able to do so in the analysis of historical languages (as there are no native speakers of 17thcentury English available to provide us with such judgments). This has the following 
implications for the analysis presented below. If the analyst wishes to make any claims on the aspectual semantics of a given construction in a historical variant of a language, they must draw on explicit contextual cues that highlight one reading over another. This makes it impossible to assume two different levels of analysis (i.e. one pertaining to the default semantics of the base verbs and another to the construal imposed on those default semantics), and therefore such an approach cannot be realistically adopted.

\section{Diachronic development in Modern English ing-nominals}

\subsection{Ing-nominals shifting from events to objects}

The claim that ing-nominals - unlike their German counterparts in -ung - convey processual semantics is quite common in the existing literature. In her elaborate corpus-based study of German ung-nominalization, Demske $(2000,2002)$ is the first to examine the workings of a semantic shift from a process reading to an object reading in German ung-nominals, which she calls 'nominalization in the literal sense'. Demske argues that, for instance, the -ungnominalization Heizung in Present-day German commonly refers to a concrete object (i.e. a 'heating installation') - Heizung referring to the 'process of heating' would be marked (also see Erich \& Rapp, 2000). Similarly, Lesung (from lesen '(to) read') in Present-day German does not typically refer to the 'process of reading', but rather to a kind of formal event or lecture. In older stages of German, however, ung-nominalizations were productively used to refer to processes (or events), and over the course of the centuries they gradually acquired new meanings through the semantic extension mechanisms of metaphor and metonymy (Hartmann, 2014; see also Panther \& Thornburg, 2001; Booij, 2010, p. 78). These new meanings comprise resulting states, but also objects (e.g. Heizung) and even agents involved in the situation expressed by the base verb (e.g. Bedienung) (Hartmann, 2014). During the 18th century, the productivity of ung-nominals decreased as the more verb-like uses started to decline (possibly through competition with German nominalized infinitives, see Hartmann (2014) and Iordăchioaia \& Werner (this issue)), resulting in increased denotational 'nouniness' of the ung-nominalization pattern. What is argued by Demske (2002, p. 88), then, is that "no such nominalization process is attested with ing-nouns in the history of English".

Yet, it has been pointed out that if verbal gerunds, which have clausal internal syntax (e.g. My family was against me having a baby) are left out of the analysis, it is possible to detect a semantic shift in ing-nomianls with nominal internal syntax (Fonteyn \& Hartmann 2016). Figure 1 illustrates this with data taken from Fonteyn \& Hartmann (2016): when we map out the relative frequency of ing-nominals referring to events (e.g. the sending of the Money [1571, PPCEME]) versus ing-nominals referring to non-eventive concepts such as bounded regions in space (locations) or time (festivities, etc.) (e.g. I came to a lodging in the Lard of Eggels Land [1630, PPCEME]; at this wedding was as plentifull as Beere or Ale [1597, PPCEME]), concrete objects (e.g. Noah remooued the couering of the Arke [1611, PPCEME]; your clothing is not so warme [1597, PPCEME]), it appears that ing-nominals increasingly associate with non-eventive meanings. 


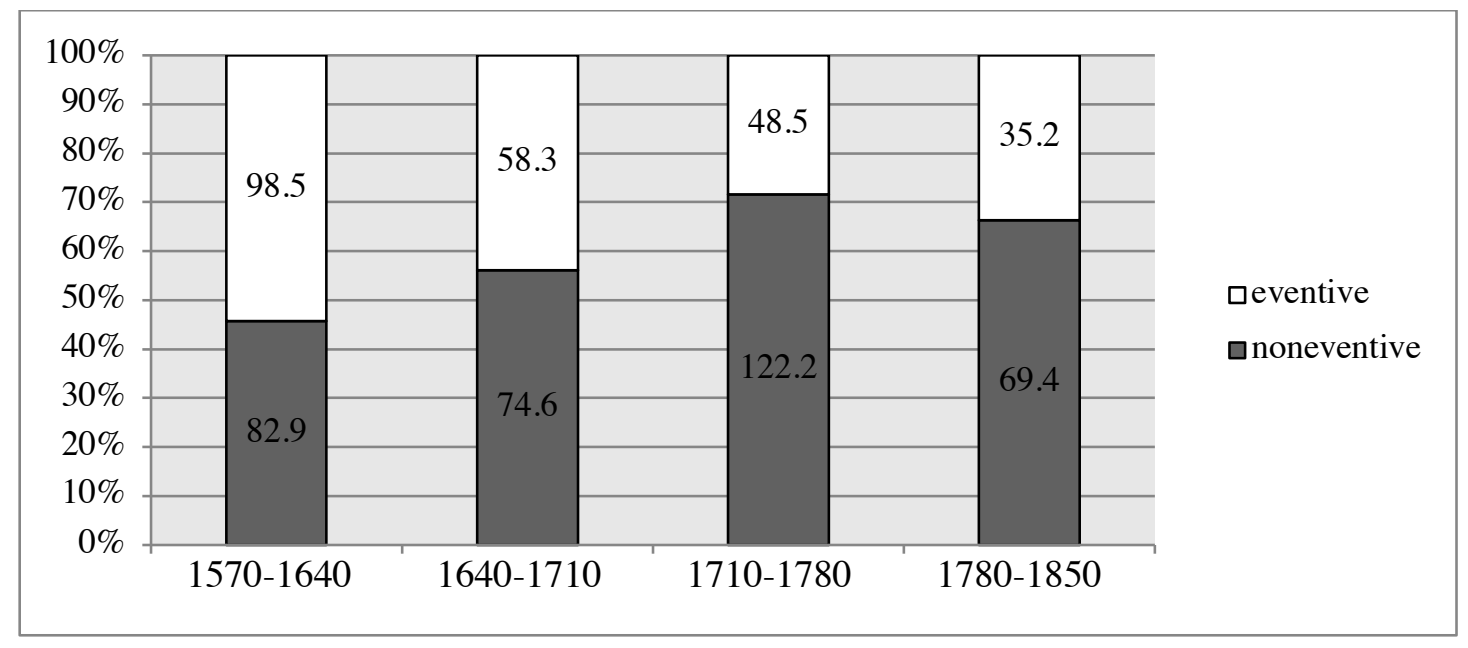

Fig. 1. Relative frequency (\%) of eventive vs. noneventive concepts (i.e. bounded regions in space/time, objects, etc.) between 1570 and 1850 (data taken from ,Fonteyn \& Hartmann 2016). The figures show the normalized frequenciesy of eventive and non-eventive ing-nominals per10,000 words.

Importantly, the observed increase in frequency of non-eventive ing-forms might not simply be due to a few lexicalized forms that are high in token frequency (as suggested by Iordăchioaia \& Werner (this issue)): Fonteyn \& Hartmann (2016) also point out that the potential productivity of non-eventive -ing (i.e. the number of hapax legomena divided by the total number of tokens instantiating the construction in question; Baayen 1992) increases throughout the Modern English period. This all suggests that it is perhaps an overstatement to claim that English ing-nominals were prevented from undergoing a shift similar to German ung-nominals from verby 'processual' semantics to resulting states, objects, and so on.

The results presented by Fonteyn \& Hartmann, however, only make a distinction between 'eventive' and 'non-eventive' semantics. In other words, they argue that the [Ving $]_{\mathrm{N}}$ pattern diachronically becomes increasingly associated with object-like semantics for all nominal ing-forms, but that within the group of 'eventive' ing-forms, no distinction is made between atelic or 'processual' readings and telic or 'result state' readings. In what follows, then, I will further address the issues raised here by presenting a corpus-based study of eventive ing-nominals (or nominal gerunds).

\subsection{Aspectual features of eventive ing-nominals (nominal gerunds) in Modern English}

Iordăchioaia \& Werner (this issue) state that their data is "selected from previous studies that document nominalizations at different language stages". They thus point that they are not the first to address the thorny issue of aspectual-semantic properties of different nominalization strategies. For English nominal gerunds alone, a range of opposing claims has been made over the past decades. The point on which there seems to be most agreement is that, in Middle English, nominal gerunds exhibited no aspectual restrictions, expressing activities as well as achievements, accomplishments, and even states (Zbierska-Sawala, 1993; Iordăchioaia \& Werner, this issue):

(4) But to knowyng of God (...), ne mai3t pou not comen but porw kno-wynge of pi-self (...). (c1390, Penn Parsed Corpus of Middle English, 2nd edition)

'But you are not able to come to knowing God [lit. 'knowing of God] but through knowing yourself [lit. 'knowing of yourself']' 
When it comes to the developments that subsequently affected the aspectual-semantic profile of nominal gerunds, opinions diverge. First, Iordăchioaia \& Werner claim that some aspectual constraints were gradually imposed on the nominal gerund. These restrictions, they argue, are most obvious when the aspectual versatility is compared of Old and Middle English nominal gerunds with those illustrated in studies on present-day nominal gerunds. The latter are said not to allow non-action predicates (e.g. *the/Kim's having of a bad feeling, *the/my being of a housewife; Lees, 1968,p. 64-65; Marchand, 1969, p. 302; Fraser, 1970; Borer 2013) and to be incompatible with telic bases (Borer, 2005; Alexiadou, Iordachaia \& Schäfer, 2011). Other studies, however, suggest that in Present-day English, the aspectual meaning of nominal gerunds is not necessarily restricted to 'actions' (see, for instance, Bauer, Lieber \& Plag (2013, pp. 207-208) as well as Heyvaert, Maekelberghe \& Buyle (this issue)).

In the remainder of this section, I will present a corpus analysis of Modern English nominal gerunds in order to get a clearer view of the historical development of their aspectual-semantic profile. The analysis presented here is based on corpus data from the Early and Late Modern period. A random sample of nominal gerunds was extracted from the Penn Parsed Corpus of Early Modern English (PPCEME) and the Penn Parsed Corpus of Modern British English (PPCMBE), comprising 296 nominal gerunds occurring between 1570 and 1710, and 277 occurring between 1780 and 1914. The aspectual classification adopted here is based on Croft (2012), whose classification of aspectual construals and distinctions largely correspond to the original four-way classification of aspectual types proposed by Vendler (1967). ${ }^{4}$ Following Smith (1991), Depraetere (1995), and Declerck (2006), an additional category of so-called semelfactives (or 'cyclic achievements' in Croft's terminology) has been distinguished, yielding five distinct aspectual categories.

Table 1. Properties of the five aspectual categories

\begin{tabular}{cccc}
\hline & stative & durative & telic \\
\hline state & + & $+(-)$ & - \\
activity & - & + & + \\
accomplishment & - & + & + \\
(ir)reversible & - & - & - \\
achievement & & - & \\
semelfactive & - & & \\
(cyclic achievement) & &
\end{tabular}

The distinction that is of interest to the present study is that of telic and atelic situations. Telic situations, i.e. accomplishments and achievements, are profiled in such a way that their endpoint and resulting state (or 'telos') $)^{5}$ are included in the situation. For instance, the Writing

\footnotetext{
${ }^{4}$ For a more elaborate discussion and overview, I refer to Croft (2012) as well as Fonteyn (2016, Ch. $6)$.

${ }^{5}$ In some models, achievements and semelfactives are not distinguished in terms of telicity but in terms of 'transitionality'. In these models, a distinction is made between the telos or 'natural endpoint' of the situation, and whether or not the situation transitions into a result state. In that case, semelfactives would be non-transitional, and achievements would be transitional (see Heyvaert, Buyle, Maekelberghe, this volume). Following Iordăchioaia \& Werner's t target article, I take telicity to be the combination of a natural endpoint and resulting state here.
} 
of the former part of this Essay implies an endpoint, i.e. when the said part of the essay is finished (cf. Section 2). The difference between $(5 \mathrm{a}-\mathrm{b})$ and $(5 \mathrm{c})$ is that, while the writing of (...) this essay implies a durative effort before the endpoint was reached (accomplishment), the breaking of his trainer's imposed fast in liquids and winning of a castle expresses a more instantaneous reaching of a result state (achievement):

a. (...) all because of his fatal addiction to the breaking of his trainer's imposed fast in liquids on the night before the battle. (1895, PPCMBE)

b. Some newes of landing of certyne Spanyardes in Irland and of winning of a castle wher they shold have taken $M=r=$ Denny a prisoner. (1587-1589, PPCEME)

c. (...) and since the Writing of the former part of this Essay, (...), observ'd, (...) that the Colour of their Hair and Skin was far less Whitish than the Danes (...) (1593, PPCEME)

Accomplishments and Achievements are also different from activities, which are not construed with any sort of 'natural' endpoint and resulting state. Conceptually, this means that states, such as not having in (6), and activities, such as preaching in (7), can in principle continue infinitely, whereas the nominal gerunds in (5) naturally finish once their endpoint is reached.

(...) they shall find that the not having of a peace lies on his side (1666-7, PPCEME)

(...) such as shall with Herod heare the preaching of Iohn Baptist to day, and to morrow condescende to haue him beheaded (1614, PPCEME)

Activities can also be made up of an iterative series of actions (multiple leaps, multiple trembles), as in example (8) (cf. Section 2):
a. (...) my Limbs were made for leaping of Ditches (1707, PPCEME)
b. Emotional causes, such as rage or fear, will cause trembling of the muscles. (1876, PPCMBE)

Another way of looking at the distinction between (telic) accomplishments and (atelic) activities is that atelic events are cumulative: every subcomponent of preaching or leaping ditches is an event of preaching or leaping ditches in itself. This 'cumulativeness'is said to underlie the fact that the progressive use of atelic situations, e.g. John was preaching, entails that John preached (Smith 1991, p. 32). This does not hold of telic situations like write the essay, as we cannot infer from He was writing the essay that He wrote the essay occurred successfully.

Finally, some authors argue that achievements, which are punctual and telic, should also be distinguished from situations that are punctual and atelic, called semelfactives. ${ }^{6}$ While achievements mark the instantaneous transition to a result state (as for instance closing >

\footnotetext{
${ }^{6}$ Note that Croft (2012) considers semelfactives as a subtype of the category of achievements called 'cyclic achievements'. This is because Croft considers all aspectual types that lack temporal duration are naturally telic. As will be pointed out below, the total number of semelfactive nominal gerunds is quite small (cf. Figure 2), and thus the decision to categorize semelfactives as telic or atelic does not significantly impact the results.
} 
being closed in example (9a), and wounding > being wounded (9b)), semelfactives are considered to be"single-stage events with no result or outcome"(Smith, 1991, p. 29). This is the case for hitting in example (9c), which merely refers to a single instantaneous moment in time that can, in principle, immediately be repeated without any reversal of the result state.

a. These marshes are at last terminated by the sudden closing of the valley at St. Maurice (1835, PPCMBE)

b. (...) then some of our Co pany told them of al the intended treacheries with the losse of two of our men, and wounding of the third (1612, PPCEME)

c. Now there are five organs or instruments of speech, in the right hitting of which, as the breath moveth from within, through the mouth, a true pronunciation of every letter is mad. (1660, PPCEME)

The results of the aspectual-semantic analysis of nominal gerunds in Late Modern English are presented in Figure 2.

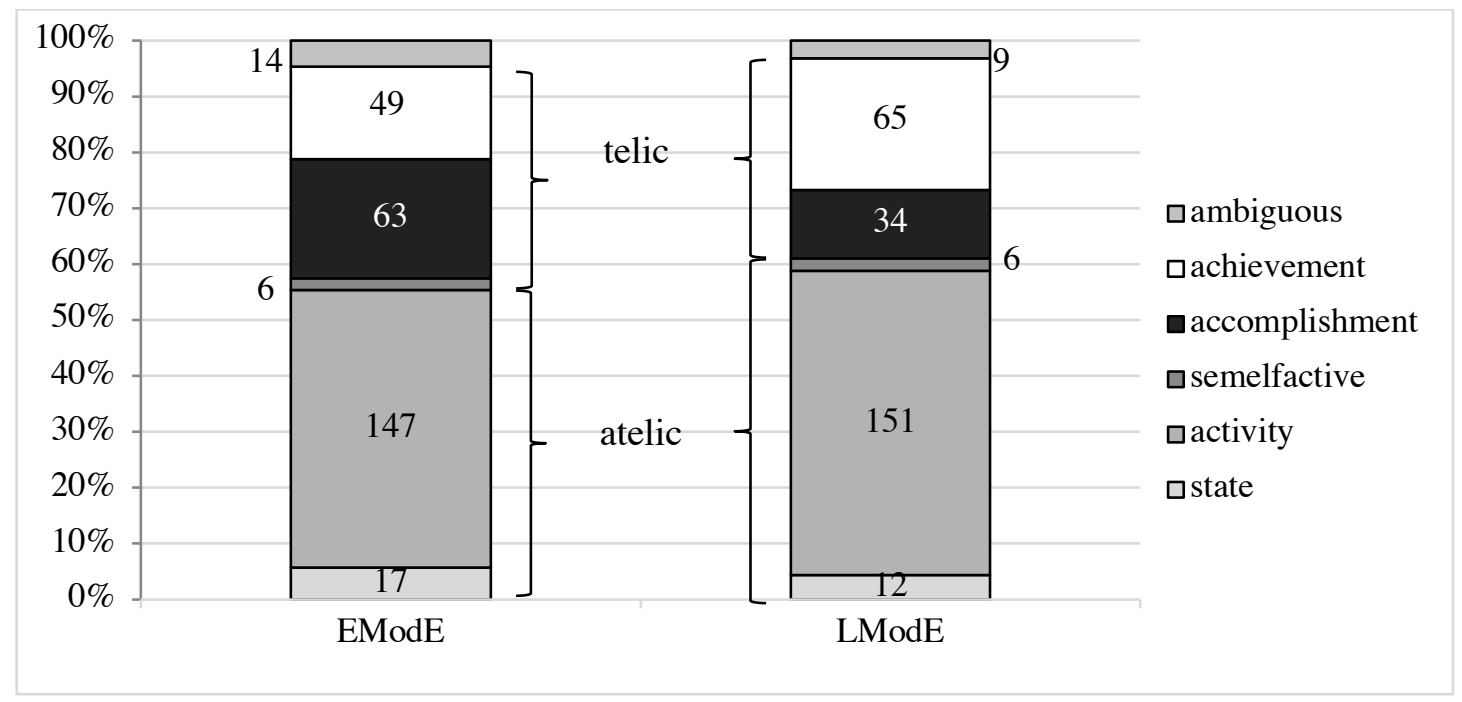

Fig. 2. Relative frequency of telic and atelic aspectual types in Early Modern English (EModE; 1570-1710) and Late Modern English (LModE; 1780-1920).

The lion's share of nominal gerunds in Early Modern English are activities (49.7\%), i.e. a dynamic, durative, and atelic event/process. The second largest group of nominal gerunds, however, is that of accomplishments $(21.3 \%)$, followed by achievements $(16.6 \%)$, which are both telic. The smallest groups are semelfactive and stative nominal gerunds, constituting only $2 \%$ and $5.7 \%$ of all cases, respectively. In Late Modern English, activities represent $54.5 \%$ of all cases, accomplishments and achievements adding up to $12.3 \%$ and $23.5 \%$, respectively. Again, semelfactive and stative nominal gerunds remain the smallest group (2.2\% and $4.3 \%)$. In sum, as much as $37.8 \%$ of all nominal gerunds in Early Modern English and $35.7 \%$ in Late Modern English are telic. It appears, then, that the distribution of aspect types in both periods is strikingly similar (the apparent decrease of telic situations is small $(\varphi$ 
$=0.053)$ and not significant $(\mathrm{p}=0.24))^{7}$, and it cannot be confirmed that nominal gerunds gradually specialize in the functional domain of atelicity in the Modern English period.

\subsection{Competition with Romance derived nominals in -age, -al, -ance, -ion, and -ment}

At first sight, the aspectual-semantic analysis of nominal gerunds in Modern English presented in Section 3.2 does not confirm the hypothesis of Iordăchioaia \& Werner, who suggest that nominal gerunds gradually developed a preference for expressing atelic situations due to competition with Romance suffixes in the Modern English period. The concept of 'competition' should be understood as "the struggle among alternative forms during the retrieval process" (Berg, 2014, p. 344). As a language user can only select one way of nominalizing a verb at a given point in time, competition implies that during retrieval there is always a winning nominalization strategy (the one that is actually encoded) and one or more losing strategies (the ones that are not encoded). If it then happens that language users over time start to opt for one possible variant recurrently and consistently in a particular context, competition can lead to linguistic change. Thus, by arguing that competition with Romance suffixes led English -ing to specialize in processual meanings, Iordăchioaia \& Werner propose the following scenario. First, an innovative set of Romance suffixes became available alongside the ing-suffix to speakers of English in Middle English. Over time, language users increasingly selected those new Romance forms over the alternative nominal gerund to express or nominalize telic events, eventually leaving ing-nominals to be selected only when an atelic event was to be expressed (or in other words, leading ing-nominals to 'specialize' in process-oriented readings). In the present section, I will suggest that the lack of observable specialization towards atelicity (or process-orientation) in the nominal gerund may be attributed to the fact that (i) the area of competition between Romance derived nominals and nominal gerunds (i.e. the verb types that can be nominalized by means of the ing-suffix as well as two or more Romance suffixes) is rather limited, and (ii) even within areas of competition, we do not observe a clear semantic distinction between ing-nominals and their derived nominal counterparts.

As the main focus of the final part of this analysis is eventive nominalizations, only nominalizations whose subject or direct object participant is expressed (in an of-phrase, e.g. the barking of the dogs, the destruction of the city) were considered. An automatic corpus search was carried out for words ending in -age, -al, -ance, -ion, -ing, and -ment (followed by $o f)$. Subsequently, all hits were manually checked for event reference, excluding forms that are not based on a $[\mathrm{V}+\text { suffix }]_{\mathrm{N}}<->$ 'event or action of V' word formation schema (such as stage, moral, elegance, station, evening, and basement). Total token frequencies of each of the different nominalization patterns are listed in Table 2 (normalized frequency per 100,000 words between brackets).

Table 2. Absolute token frequency and type frequency of the different nominalization strategies in Early Modern English (normalized frequencies per 100,000 words between brackets).

\section{$\begin{array}{llllll}1500-1569 & 1570-1639 & 1640-1709 & 1710-1779 & 1780-1849 & 1850-1920\end{array}$}

\footnotetext{
${ }^{7}$ If semelfactive nominal gerunds are considered to be telic due to their lack of temporal duration (cf. Croft 2012), 39.8\% of all nominal gerunds in Early Modern English and 38.9\% of all nominal gerunds in late Modern English would be telic. In that case, the effect size of the apparent decrease is even smaller $(\varphi=0.027)$, and also not significant $(p=0.58)$.
} 
$\begin{array}{llllll}\text { e1 } & \text { e2 } & \text { e3 } & 11 & 12 & 13\end{array}$

\begin{tabular}{ccccccc}
\hline -age & $23(4)$ & $32(5)$ & $41(7)$ & $21(7)$ & $41(11)$ & $21(7)$ \\
types & 10 & 6 & 7 & 8 & 9 & 11 \\
-al & $9(2)$ & $13(2)$ & $22(4)$ & $32(11)$ & $34(9)$ & $31(11)$ \\
types & 8 & 8 & 10 & 11 & 9 & 15 \\
-ance & $36(6)$ & $106(16)$ & $118(21)$ & $104(35)$ & $91(25)$ & $70(25)$ \\
types & 21 & 30 & 32 & 27 & 27 & 33 \\
-ion & $392(68)$ & $598(92)$ & $636(113)$ & $525(176)$ & $645(175)$ & $523(186)$ \\
types & 159 & 196 & 218 & 178 & 233 & 218 \\
-ing & $678(118)$ & $774(119)$ & $400(71)$ & $175(59)$ & $178(48)$ & $198(70)$ \\
types & 269 & 336 & 213 & 92 & 75 & 95 \\
-ment & $122(21)$ & $137(21)$ & $144(26)$ & $117(39)$ & $124(34)$ & $117(42)$ \\
types & 43 & 40 & 47 & 40 & 38 & 40 \\
total & $1260(222)$ & $1660(264)$ & $1361(251)$ & $974(326)$ & $1114(302)$ & $960(341)$ \\
types & 486 & 555 & 486 & 341 & 388 & 409 \\
\hline
\end{tabular}

The token frequencies listed in Table 2 are visualised in Figure 3. Overall, in terms of token frequency (as well as type frequency), the main nominalization strategies in the PPCEME appear to involve -ing and -ion, followed by -ment and -ance, while -al and -age are fairly infrequent at the period under investigation. The figures also suggest that word formation products with Romance suffixes become increasingly popular as the Modern English period progresses while nominal gerunds decrease in token frequency, but only the former tendency seems to be significant (Romance: $\tau=0.87, p=0.02$; Nominal Gerund: $\tau=-0.6, p=0.14$ ). 


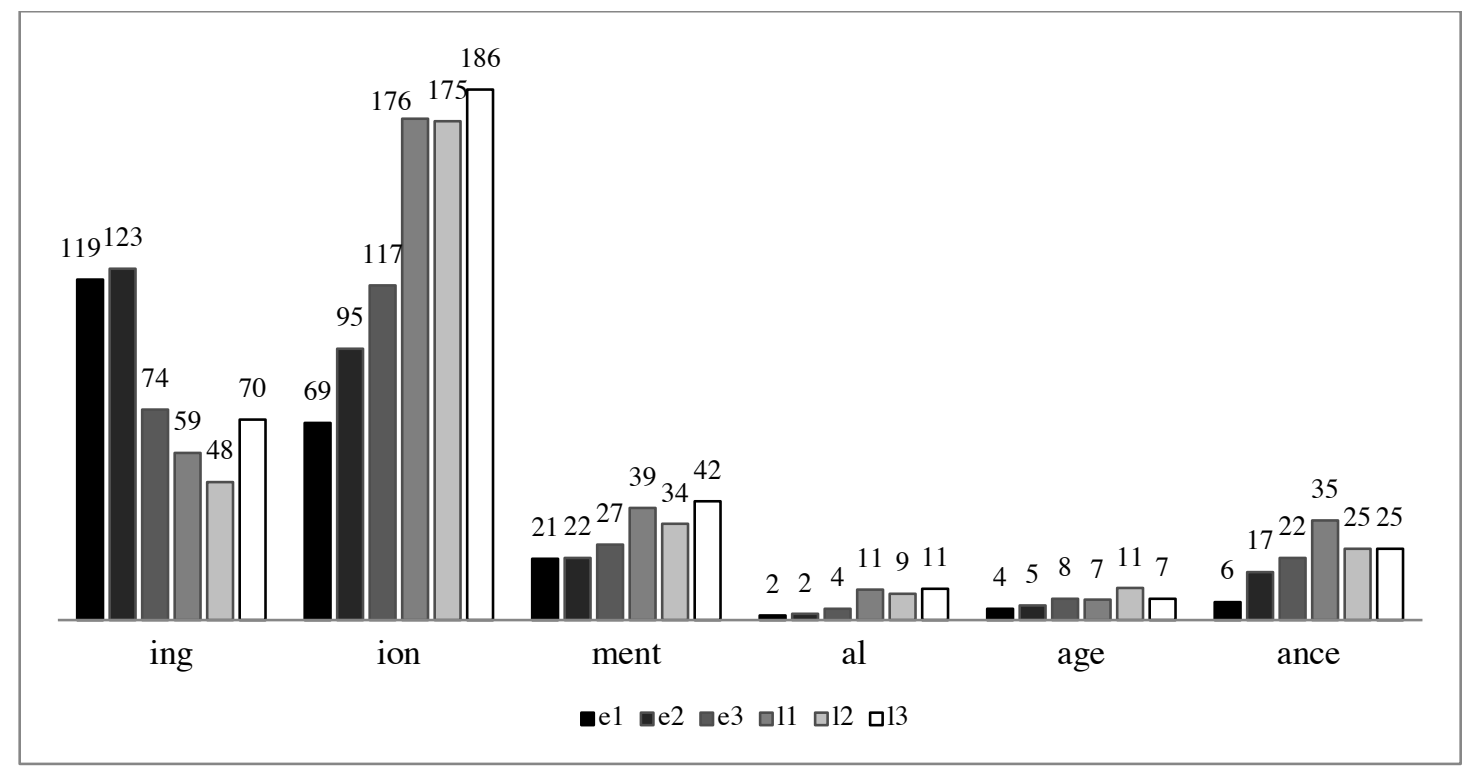

Fig. 3. Normalized token frequency per 100,000 words for each suffix, per period.

In terms of the number of different verb lexemes attested in nominalizations for each period, type frequencies fluctuate between 341 and 555 unique verbs, without any clear upward or downward trend being detectable. Interestingly, only a very small share of them (2\%-10\%) occurs in two or more of the nominalization patterns investigated here. The proportions are illustrated in Figure 4:

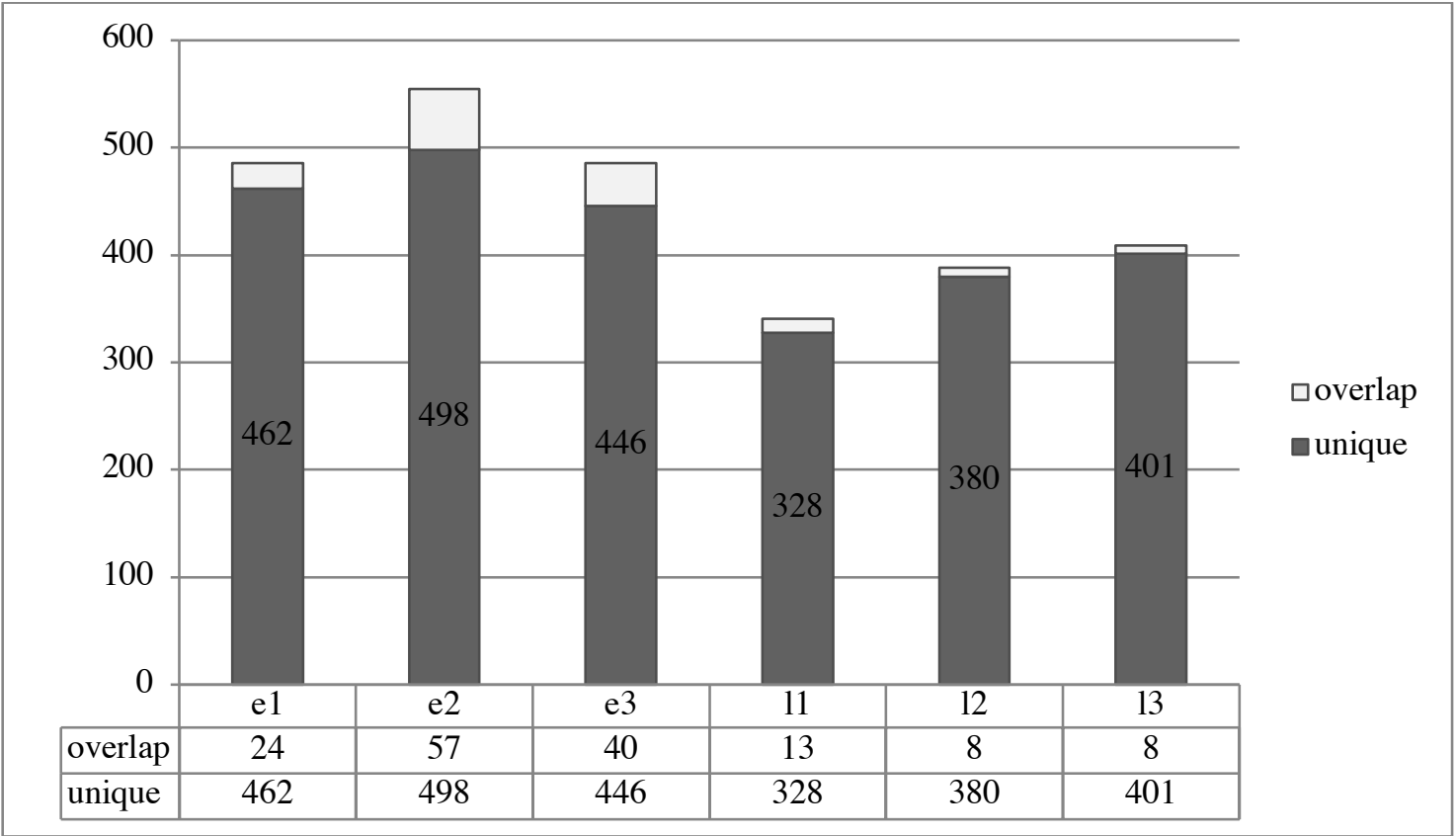

Fig. 4. Number of different verb types occurring as either nominal gerunds, or derived nominals in -ion, -ment, -al, -age, or -ance (unique) in the PPCEME and PPCMBE. The verb types in the group 'overlap' occurred in at least two of the nominalization patterns listed, while the ones marked 'unique' only occurred in one. 
Within the face of these figures, a few observations can be made. First, it should be noted that the Penn Corpus only represents a (smallish) sample of the Modern English language, and it cannot therefore be excluded that many of the verb lexemes have the potential to be nominalized by means of more than one the suffixes under investigation, but were simply not attested in more than one nominalization strategy (e.g. clearing potentially competes with clearance, even though the latter was not attested in the sample). Still, while the absence of alternative nominalization strategies in the Penn Corpus does not mean that their formation was entirely impossible in Modern English, it does indicate that the alternatives were possibly not common enough to occur in the sample of Modern English that the PPCEME and PPCMBE offer. The relatively small degree of overlap attested in the sample, can therefore be linked to Iordăchioaia \& Werner's observation that the Romance suffixes most commonly combine with Latinate verbs, while nominal gerunds are formed more freely with native English verbs (e.g. Marchand, 1969; Dalton-Puffer, 1996). Importantly, the relatively large number of telic situations expressed by nominal gerunds attested in Section 3.2 is not incompatible with this claim, and it can possibly be attributed to nominal gerunds formed with originally Common Germanic verbs like drown, kill, or break off (10):

(10) a. Here dined with me also Mrs. Batters, poor woman, now left a sad widow by the drowning of her husband the other day. (1666-7, PPCEME)

b. (...) both of them concluding, that the Trumpet \& Vial was now powering out; and my L. S. Asaph attributing the Killing of the two Witnesses, to the utter destruction of the Cevenes Protestants (1688-1689, PPCEME)

c. Next, we may also as plainly see the reason of its shining quality and that is from the even breaking off of the stick. (1665, PPCEME)

However, in the contexts where they do compete (i.e. where a nominalization can be formed with -ing and one or more Romance suffix, as in example (11)), Iordăchioaia \& Werner suggest that Romance derived nominals (in -al, -ion, -ment, etc.) were involved in causing a specialization of English ing-nominals: using the classic example of the destructing/destruction alternation pair, they argue that "the derived nominal expresses the result reading, while -ing yields a process interpretation" (Iordăchioaia\& Werner, this issue).

(11) a. The pain he feels upon any motion of the limb, is intolerably severe. (1807, PPCMBE)

b. (...) in case the movement of his troops became necessary (1815, PPCMBE)

c. In these lay great multitude of infirm persons, of blind, lame, withered, looking for the moving of the water. (1796, PPCMBE)

To shed some more light on the exact workings of the competition between Romance derived nominals and nominal gerunds in Modern English, the final part of the analysis will provide a more in-depth comparison of the alternating forms found in the PPCEME and PPCMBE by considering them in their full usage context.

A quick glance at the alternating pairs in Early Modern English reveals that all nominalization patterns under investigation here pattern quite similarly and are often used in coordination, as evidenced by examples such as $(12 \mathrm{a}-\mathrm{c})$ : 
(12) a. For as saith Iacobus Ruffus that to the perfection and accomplishing of the foresaid Cure called, The Euill by the King, or Queene Cured he doth reduce it into sixe Intentions Chirurgicall, as followeth. (1602, PPCEME)

b. they pretended nothing against the alleageance nor fidelitie which they ought to the King, neyther to gather to any other ende an armie, but only for the sauing of their persons, and for the better gouernement of the common wealth (1580, PPCEME)

c. (...) and all such Exportation Transportation carrying or conveying of any the Goods Wares or Comodities in this Act mentioned is hereby declared and adjudged to be a common and publicke Nusance (1660, PPCEME)

In some examples, we even find that the linguistic contexts in which Romance derived nominals and nominal gerunds are used are nearly identical. This is the case in the examples in (13):

(13) a. (...) aiding abetting or assisting in ... Exportation of Wooll or any other of the Co modities as (1690, PPCEME)

b. (...) aiding abetting or assisting in ... exporting of them or any of them (1690, PPCEME)

Examples as in (13) quite prominently show that it is difficult to maintain that the nominal gerund exporting of them has a process-focused or atelic reading, whereas the derived nominal Exportation expresses (or at least additionally allows) a result-focused or telic reading. Similarly, given the absence of native speaker intuitions and acceptability judgments, it seems hardly possible to convincingly argue that the nominal gerund refusing in (14a) is more process-focused than the derived nominal refusal in (14b):

(14) a. (...) the Kinges Highnes wolde as they saide take displeasure inough towarde me for the only refusal of the othe. (1529, PPCEME)

b. (...) both that peryll and all other that myght put my bodie in peryll of death by the refusing of this othe. (1533-5, PPCEME)

Still, it is not impossible to investigate whether a nominalization in Modern English has process- or result-focused semantics, as cues in the linguistic context may trigger a particular reading (or exclude another). For instance, the processual semantics of determination in (15a) are highlighted by the predicate extending, which implies that the determination of the fault is an (ongoing, unfinished) process. Similarly, in (15b), prosecution and advancement are construed as a process that has not yet reached completion, as it has been diverted and interrupted.

(15) a. the Judges may use their Equitie, extending the determinacion of the fault as they thinke good: (1554, PPCEME)

b. (...) that diuerteth and interrupteth the prosecution and aduauncement of knowledge (1605, PPCEME)

The processual semantics of the nominalization can also be marked by adjectives, such as continual in (16): 
(16) The first is, that the continual mouing of the hard bone might not be done in a iuncture (1548, PPCEME)

Finally, it is equally possible for adjectives to highlight the resulting state of the process rather than the process itself. In (17), for instance, the adjective perfect modifies the state of completion of the nominal gerund, in which case a result state reading becomes more likely (also see adjective even in example (11c)):

(17) And for the better Discoverie of the Offences aforesaide and the more $\boldsymbol{p} \sim$ fecte accomplisshing of the p $\sim$ misses, it may be also enacted, That (...) (1590, PPCEME)

It is such contextual cues that I have taken to support a processual or a result state reading in the analysis presented here. If no such explicit contextual cues were present, the example was categorized as 'unmarked'. This would be the case for the examples in (18) and (19) below. As contextual cues are lacking which either emphasise a resulting state or highlight processual meanings, we cannot be absolutely certain that continuing in (18a) or electing in (19a) refer to processes only, or that continuation in (18b) and election in (19b) refer to resulting states:

(18) a. a continuing of the war must undo us (1666-7, PPCEME)

b. Lastly remembering my humble duty with a continuation of your good favor towards me I commit yow etc. (1587-9, PPCEME)

(19) a. (...) to bee directed for the electing of the Knights Citizens Barons and Burgesses (1640, PPCEME)

b. (...) shall forthwith without further Warrant or direction proceed to the Election of such Knight or Knights Citizen or Citizens Burgesse (1640, PPCEME)

Finally, if we wish to compare nominal gerunds with their equivalent derived nominal counterparts with a Romance suffix, we need to be aware that some of the attestations are in fact 'false pairs'. The nominal gerund in (20) is based on the base verb compass, which is a loan from French (compasser, cf. OED) meaning 'to plan, or to devise' (OED, s.v. compass, v.1). The derived nominal compassion in (21), on the other hand, was borrowed from French in its entirety, and expresses an entirely different meaning, i.e. a feeling of sympathy.

(20) (...) and this was judged Treason, and a compassing of the King's Death. (1571, PPCEME)

(21) (...) but by such as themselves beemones \& takes compassion of, as tho they wold bring the sick (1593, PPCEME)

Because of the different meanings of its elements, a pair such as compassing-compassion will not serve to illustrate whether nominal gerund and derived nominals impose different (i.e. process-focused vs. result-focused) construals. As such, these kinds of pairs have been excluded from the analysis.

The results of the semantic analysis of nominal gerunds and their derived nominal counterparts are visualised in Figure 5 and Figure 6 respectively. Given the relatively low number of observations analyzed in the Late Modern period, we should be cautious about drawing strong conclusions based on these findings. There are, however, a few diachronic 
trends that I wish to draw attention to. What is perhaps most evident from the results in Figure 5 and 6 is that, with the exception of the first period under investigation, the majority of nominal gerunds (48\%-74\%) and Romance derived nominals $(50 \%-78 \%)$ occurs in unmarked contexts, in which neither readings is entirely ruled out. In the first period (1500$1570)$, exclusively processual readings are the most frequent for ing-nominals (62\%), whereas their derived nominal counterparts in a Romance suffix are predominantly result-oriented (50\%), which would be in line with Iordăchioaia \& Werner's hypothesis. However, the overall trend we observe does not seem to be one in which nominal gerunds gradually specialize in explicit processual readings. Instead, while the overall usage profile of -age, -al, -ance, -ion, and -ment appears to remain fairly stable in the sample (the observed decrease of result and process readings being non-significant, $\tau=-0.07$ and $\mathrm{p}=1$ and $\tau=-0.55, \mathrm{p}=0.126$ respectively), there does appear to be a significant decrease of nominal gerunds ( $\tau=-0.87, p=$ 0.017 ) with explicitly process-focused readings (and a strong, yet non-significant increase of nominal gerunds with result-oriented readings: $\tau=0.73, \mathrm{p}=0.056$ ).

In sum, then, the data seem to confirm Iordăchioaia \& Werner's hypothesis that the language users have distinct preferences for nominal gerunds or Romance derived nominals. However, the data do not support their suggestion that an aspectual-semantic distinction develops between nominal gerunds (expressing process meaning) and derived nominals (expressing result meaning) in the contexts where they do overlap (i.e. where a nominalization can be formed with -ing or a Romance suffix), and there are no clear indications that an aspectual-semantic 'preference' of result or process emerges for either strategy.

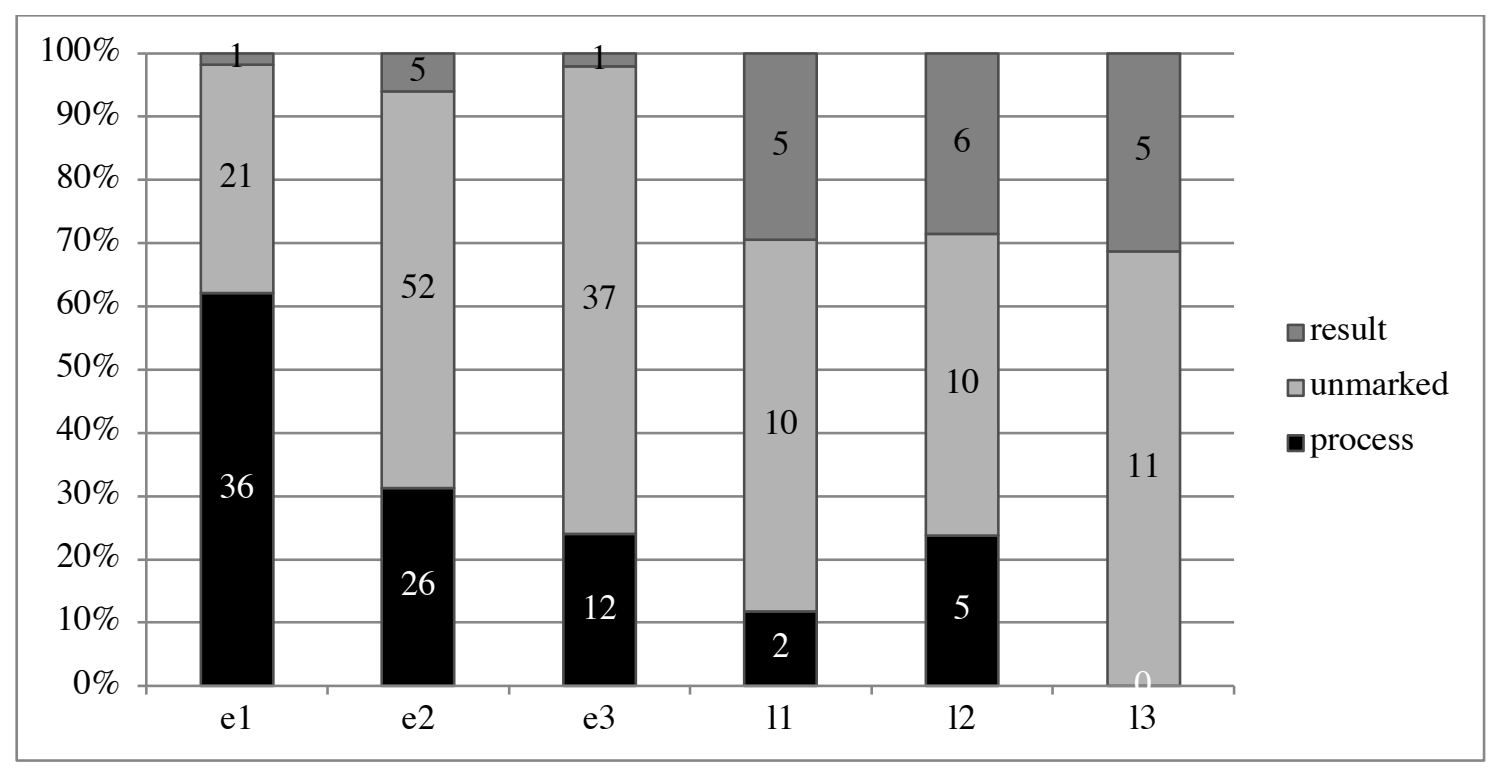

Fig. 5. Relative frequency (\%) of process-oriented, result-oriented, and unmarked readings in Modern English nominal gerunds 


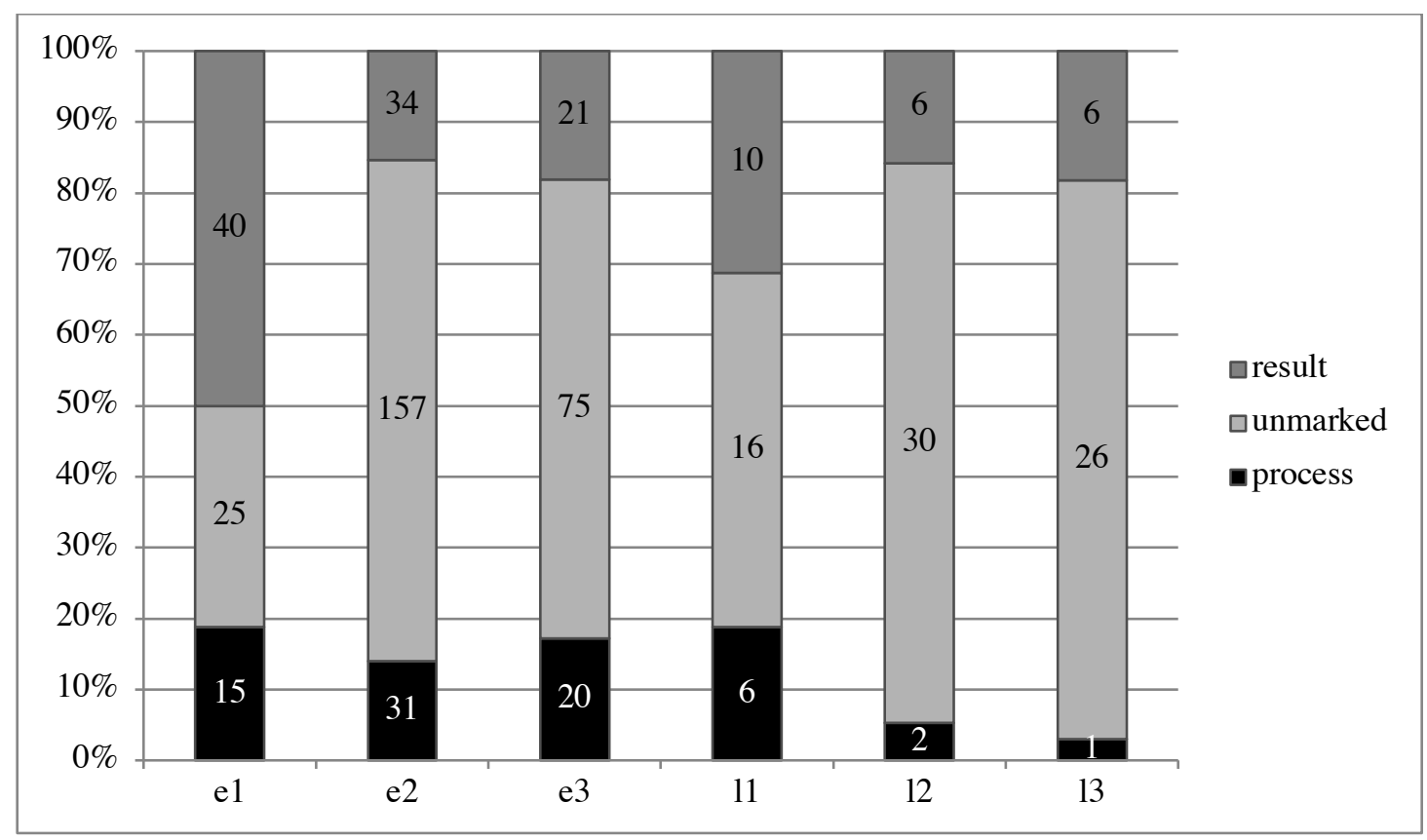

Fig. 6. Relative frequency (\%) of process-oriented, result-oriented, and unmarked readings in Modern English Romance derived nominals in -age, -al, -ance, -ion, -ment.

\section{Conclusion}

Bringing together the various corpus-based observations presented in this article, we can now map out the (aspectual-)semantic profile of English ing-nominals in Modern English (Figure 7).

EVENTIVE

NON-EVENTIVE

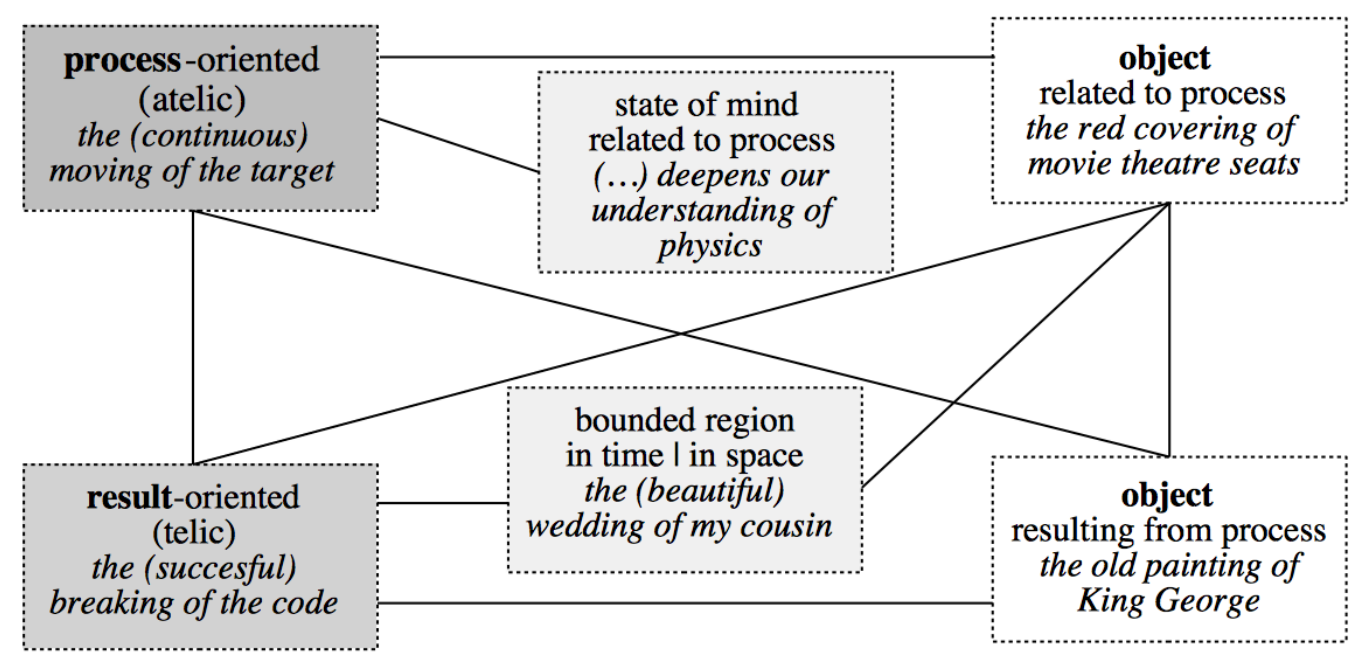

Fig. 7. A conceptual-semantic network for ing-nominals (inspired by Hartmann, 2014, Figure 4)

What is perhaps most striking is that the data cannot confirm that English ing-nominals specialized in predominantly processual meanings. Rather, the semantics of ing-nominals 
appear to be intriguingly versatile: not only are they used with non-eventive meanings (Section 3.1; see also Fonteyn \& Hartmann, 2016), they are also quite commonly used to express result-oriented (telic) as well as processual (atelic) situations (Section 3.2).

The versatility of ing-nominals of course varies across forms: a form such as building covers several eventive (telic and atelic) and non-eventive (object-like) meanings (e.g. building houses, building a house, that old building), while a form such as for instance exercising does not. In their discussion, Iordăchioaia \& Werner explain that the (exclusively) processual interpretation of ing-nominals may result from competition with Romance derived nominals in -age, -al, ance, -ion, and -ment in the course of the Modern English period. However, the data analysis in Section 3.3 indicated that there is only a relatively small amount of overlap between English ing-nominals and Romance derived nominals, suggesting that the actual area of competition between these two nominalization types might have been rather limited. Moreover, the analysis did not provide any clear support for the hypothesis that Romance derived nominals led to a specialization of ing-nominals in processual semantics. In sum, the diachronic trends revealed in the present response paper point not to specialization but to an extension or retention of the conceptual network expressed by English ing-nominals: there is a growing proportion of non-eventive ing-nominals in Modern English, and within the eventive group the proportion of process-oriented (or atelic) and result oriented (or telic) nominal gerunds remains relatively stable over time. Overall, I think a larger dataset is required to make more definite claims on the subject. However, I would like to offer a suggestion as to why ing-nominals may become more delineated and non-eventive (like German ung-nominals) while simultaneously retaining their processual uses (unlike many German ung-nominals; see the contribuitons by Iordăchioaia \& Werner, Demske, and Hartmann in this issue).

One important factor that has influenced the development of English ing-nominals and that has largely been overlooked in Iordăchioaia \& Werner's study is that Romance derived nominals are not the only functional competitor of English ing-nominals. In fact, ingnominals also compete with zero-derived nominals (Fonteyn \& Maekelberghe, forthc..) and perhaps most importantly - with verbal gerunds (e.g. De Smet, 2008, 2013). Competition between alternative forms can be weaker or stronger depending on the phonological and semantic similarity between a form and its competitor (Fay \& Cutler, 1977), and the frequency of the competitor (Vitevitch, 1997). Given the high frequency of verbal gerunds in Present-day and Modern English (De Smet, 2013; Maekelberghe, 2017) and the formal identity of the ing-suffix, we cannot underestimate the effects of the competition with verbal gerunds on the intriguingly complex diachronic development of nominal gerunds (see, e.g., De Smet, 2008; Fonteyn, 2016). From the present response article, it should become clear that it is hardly possible to accurately capture such complex developments without digging into the data vertically - to gather varied and representative attestations - but also horizontally to consider the observed stability or change against the background of a wide range of phonologically and semantically related constructions.

\section{References}

Alexiadou, A. (2013). Nominal vs. Verbal -ing Constructions and the Development of the English Progressive. English Linguistics Research 2(2), 126-140. 
Alexiadou, A., Iordachaia, G. \& F. Shäfer. (2011). Scaling the variation in Romance and Germanic nominalizations. In P. Sleeman, H. Perridon (eds.), The Noun Phrase in Romance and Germanic: Structure, variation, and change, 25-40. Amsterdam: John Benjamins.

Baayen, H. R. (1992). Quantitative aspects of morphological productivity. In G. Booij and J. Van Marle (eds.), Yearbook of Morphology 1991, 109-150. Dordrecht: Foris.

Bates, E. \& B. MacWhinney. (1982). Functionalist approaches to grammar. In E. Wanner \& L. R. Gleitman (eds.), Language Acquisition: the state of the art, 173-218. Cambridge: Cambridge University Press.

Bauer, L., Lieber, R. \& I. Plag. (2013). The Oxford Reference Guide to English Morphology. Oxford: Oxford University Press.

Berg, Th. (2014). Competition as a unifying concept for the study of language. The Mental Lexicon 9(2), 338-370.

Binnick, R. I. (1991). Time and the verb. Oxford: Oxford University Press.

Bolinger, D. (1980). Language the Loaded Weapon: The Use \& Abuse of Language Today. London: Longman.

Booij, G. (2010). Construction morphology. Oxford: Oxford University Press.

Borer, H. (2005). Structuring sense. Oxford: Oxford University Press.

Borer, H. (2013). Talking form. Oxford: Oxford University Press.

Brinton, L. J. (1988). The development of aspectual systems: aspectualizers and post-verbal particles. Cambridge: Cambridge University Press.

Comrie, B. (1976). The syntax of action nominal. A cross-language study. Lingua 40, 177201.

Croft, W. (1991). Syntactic categories and grammatical relations: The cognitive organization of information. Chicago, IL: University of Chicago Press.

Croft, W. (2000). Explaining language change: an evolutionary approach. Second edition (revised). Oxford: Oxford University Press.

Croft, W. (2001). Radical Construction Grammar: Syntactic theory in typological perspective. Oxford: Oxford University Press.

Croft, W. (2012). Verbs. Aspect and Causal Structure. Oxford: Oxford University Press.

Dahl, Ö. (1985). Tense and Aspect Systems. Oxford: Blackwell.

Dalton-Puffer, C. (1996). The French Influence on English Morphology. A Corpus-Based Study of Derivation. Berlin: Mouton De Gruyter.

De Smet, H. (2008). Functional motivations in the development of nominal and verbal gerunds in Middle and Early Modern English. English Language and Linguistics 12(1), $55-102$. 
De Smet, H. (2013). Spreading patterns: Diffusional change in the English system of complementation. Oxford: Oxford University Press.

De Smet, H. \& L. Heyvaert. (2011). The meaning of present participles. English Language and Linguistics 15, 473-498.

Declerck, R. (2006). The Grammar of the English tense System: A comprehensive analysis. Berlin: Mouton de Gruyter.

Demske, U. (2000). Zur Geschichte der ung-Nominalisierung im Deutschen. Ein Wandel morphologischer Produktivität. Beiträge zur Geschichte der deutschen Sprache un Literatur 122, 365-411.

Demske, U. (2002). Nominalization and Argument Structure in Early New High German. ZAS Papers in Linguistics 27, 67-90.

Depraetere, I. (1995). On the Necessity of Distinguishing between (Un)Boundedness and (A)Telicity. Linguistics and Philosophy 18(1), 1-19.

Dowty, D. R. (1979). Word Meaning and Montague Grammar: The Semantics of Verbs and Times in Generative Semantics and in Montague's PTQ. Dordrecht: Reidel.

Ehrich, V. \& I. Rapp. (2000). Sortale Bedeutung und Argumentstruktur: ungNominalisierungen im Deutschen. Zeitschrift für Sprachwissenschaft 19, 245-303.

Fay, D. \& A. Cutler. (1977). Malapropisms and the Structure of the Mental Lexicon. Linguistic Inquiry 8(3), 505-520.

Fraser, B. (1970). Some remarks on the action nominalization in English. In R. A. Jacobs \& P. S. Rosenbaum (eds.), Readings in English transformational grammar, 83-98. Waltham: Ginn.

Fonteyn, L. (2016). Categoriality in language change: the case of the English gerund. Doctoral thesis KU Leuven.

Fonteyn, L. \& S. Hartmann (2016). Usage-based perspectives on diachronic morphology: A mixed-methods approach towards English ing-nominals. Linguistics Vanguard 2(1). doi.org/10.1515/lingvan-2016-0057

Fonteyn, L. \& C. Maekelberghe (forthc.). Competing motivations in the diachronic nominalization of English gerunds. Diachronica.

Freed, A. F. (1979). The semantics of English aspectual complementation. Dordrecht, Boston and London: D. Reidel.

Gentner, D. (1981). Some interesting differences between verbs and nouns. Cognition and Brain Theory 4, $161-178$.

Gries, S. Th. \& A. Stefanowitsch. (2004). Extending collostructional analysis: A corpusbased perspective on 'alternations'. International Journal of Corpus Linguistics 9(1), 97-129.

Hartmann, S. (2014). "Nominalization" taken literally. A diachronic corpus study of German word-formation patterns. Italian Journal of Linguistics 26, 123-156. 
Herweg, M. (1991). A critical examination of two classical approaches to aspect. Journal of Semantics 8, 363-402.

Hopper, P. J. \& S. A.Thompson. (1984). The Discourse Basis for Lexical Categories in Universal Grammar, Language 60, 703-752.

Hopper, P. J. \& S. A. Thompson. (1985). The iconicity of the universal categories 'noun' and 'verb'. In J. Haiman (ed.), Iconicity in Syntax, 151-186. Amsterdam: John Benjamins.

Janda, L. (2008). Aspectual clusters of Russian verbs. Studies in Language 31, 607-648.

Langacker, R. W. (1987). Nouns and Verbs. Language 63(1), 53-94.

Langacker, R. W. (2008a). Cognitive Grammar. A basic Introduction. Oxford: Oxford University Press.

Langacker, R. W. (2008b). Sequential and Summary Scanning: A Reply. Cognitive Linguistics 19, 571-584.

Lees, R. B. (1968). The Grammar of English Nominalizations. The Hague: Mouton De Gruyter.

Lyons, J. (1968). Introduction to Theoretical Linguistics. Cambridge: Cambridge University Press.

Lyons, J. (1977). Semantics. Vol 2. Cambridge: Cambridge University Press.

Maekelberghe, C. (2017). The English gerund revisited: Exploring semantic differences through collocational analysis. Corpus Linguistics and Linguistic Theory. [https://doi.org/10.1515/cllt-2016-0054]

Marchand, H. (1969). The Categories and Types of Present-Day English Word-Formation. Second edition. München: Beck.

Michaelis, L. A. (2004). Type shifting in construction grammar: An integrated approach to aspectual coercion. Cognitive Linguistics 15(1), 1-67.

Mihatsch, W. (2009). Nouns are things: Evidence for a grammatical metaphor? In K.-U. Panther, L. L. Thornburg, A. Barcelona (eds.), Metonymy and metaphor in grammar, 75-97. Amsterdam: John Benjamins.

Mittwoch, A. (1980). The Grammar of Duration. Studies in Language 4, 201-227.

Moens, M. (1987). Tense, aspect and temporal reference. $\mathrm{PhD}$ dissertation, University of Edinburgh.

Moens, M. \& M. Steedman. (1988). Temporal ontology and temporal reference. Computational Linguistics 14(2), 15-28.

Mommer, K. E. (1986). Theoretical Issues Concerning Inherent Aspect and the Perfect in English, Cebaari and Swahili. PhD dissertation, Northwestern University, Evanston, Illinois.

Mourelatos, A. (1981). Events, processes, and states. In P. J. Tedeschi, A. Zaenen \& S. R. Anderson (eds.), Tense and Aspect, 191-212. New York: Academic Press. 
Nordenfelt, L. (1977). Events, Actions, and Ordinary Language. Lund: Doxa.

Panagl, O. (1987). Productivity and Diachronic Change in Morphology. In W. U. Dressler (ed.), Leitmotifs in Natural Morphology, 127-151. Amsterdam: John Benjamins.

Panther, K.-U. \& L. Thornberg. (2001). A Conceptual Analysis of English -er Nominals. In M. Pütz, S. Niemeier \& R. Dirven (eds.), Applied Cognitive Linguistics. Vol. 2: Language Pedagogy, 149-200. Berlin: Mouton De Gruyter.

Parsons, T. (1990). Events in the semantics of English: a study in subatomic semantics. Cambridge, Mass.: MIT Press.

Poutsma, H. (1926). A Grammar of Late Modern English. Groningen: Noordhoff.

Rappaport Hovav, M. \& Levin. (2010). Reflections on Manner/Result Complementarity. In E. Doron, M. Rappaport Hovav \& I. Sichel (eds.), Syntax, Lexical Semantics, and Event Structure, 21-38. Oxford: Oxford University Press.

Sapir, E. (1921). Language. New York: Harcourt Brace.

Sasse, H.-J. (2002). Recent activity in the theory of aspect: Accomplishments, achievements, or just non-progressive state? Linguistic Typology 6, 199-271.

Schmid, H.-J. (1999). Cognitive effects of shells nouns. In K. Van Hoek, A. A. Kibrik, L. Noordman (eds.), Discourse Studies in Cognitive Linguistics: Selected papers from the 5th International Cognitive Linguistics Conference, 111-132. Amsterdam: John Benjamins.

Shi, Z. (1990). On the Inherent Aspectual Properties of NPs, Verbs, Sentences and the Decomposition of Perfectivity and Inchoativity. Word 41, 47-67.

Smith, C. S. (1991). The Parameter of Aspect. Dordrecht: Kluwer.

Smith, C. S. (1997). The Parameter of Aspect. Second edition. Dordrecht: Kluwer.

Taylor, J. R. (1995). Linguistic Categorization. Second Edition. Oxford: Claredon Press.

Vendler, Z. (1967). Linguistics in Philosophy. Ithaca, NY: Cornell University Press.

Verkuyl, H. J. (1972). On the compositional nature of the aspects. Dordrecht: D. Reidel.

Vitevitch, M. S. (1997). The neighbourhood characteristics of malapropisms. Language and Speech 40, 211-228.

Vlach, F. (1981). The semantics of the progressive. In P. J. Tedeschi, A. Zaenen \& S. R. Anderson (eds.) Tense and Aspect, 271-292. New York: Academic Press.

Zbierska-Sawala, A. (1993). Early Middle English Word Formation: Semantic Aspects of Derivational Affixation in the AB Language. Frankfurt: Peter Lang Verlag. 